\title{
環境基本法
}

\author{
畠山史 郎* \\ 東京農工大学・大学院農学研究院
}

（2015年5月 28 日受理）

\section{Basic Environment Law}

\author{
Shiro Hatakeyama \\ Institute of Agriculture, Graduate School of Tokyo University of Agriculture and Technology, \\ 3-5-8 Saiwaicho, Fuchu, Tokyo 183-8509, Japan
}

Keywords: environmental quality standard, air pollution, water pollution, soil contamination, dioxins.

は じめに

環境基本法は日本の環境政策の根幹となる事項を定めた基 本法であって, その中には環境基準が定められ, 環境基本計 画が盛り込まれていて, 国や地方公共団体さらには国民が推 進すべき具体的な事柄について定めるとともに，施策の方向 性を示す指針ともなっている，そのためより細かな具体的施 策は，この中に示された規程に基づき，個別の法制上または 財政上の措置によって実施される。平成 5年11月19日に制 定されその後何回か改訂されている. 全条文は環境省の HP （http://law.e-gov.go.jp/htmldata/H05/H05HO091.html）か ら見ることができる.

本基本法の構成は

第一章 総則

第二章＼cjkstart環境の保全に関する基本的施策

第一節 施策の策定等に係る指針

第二節 環境基本計画

第三節 環境基準

第四節 特定地域における公害の防止

\footnotetext{
* $=183-8509$ 東京都府中市幸町 3-5-8

E-mail: hatashir@cc.tuat.ac.jp

(c) 日本農薬学会
}

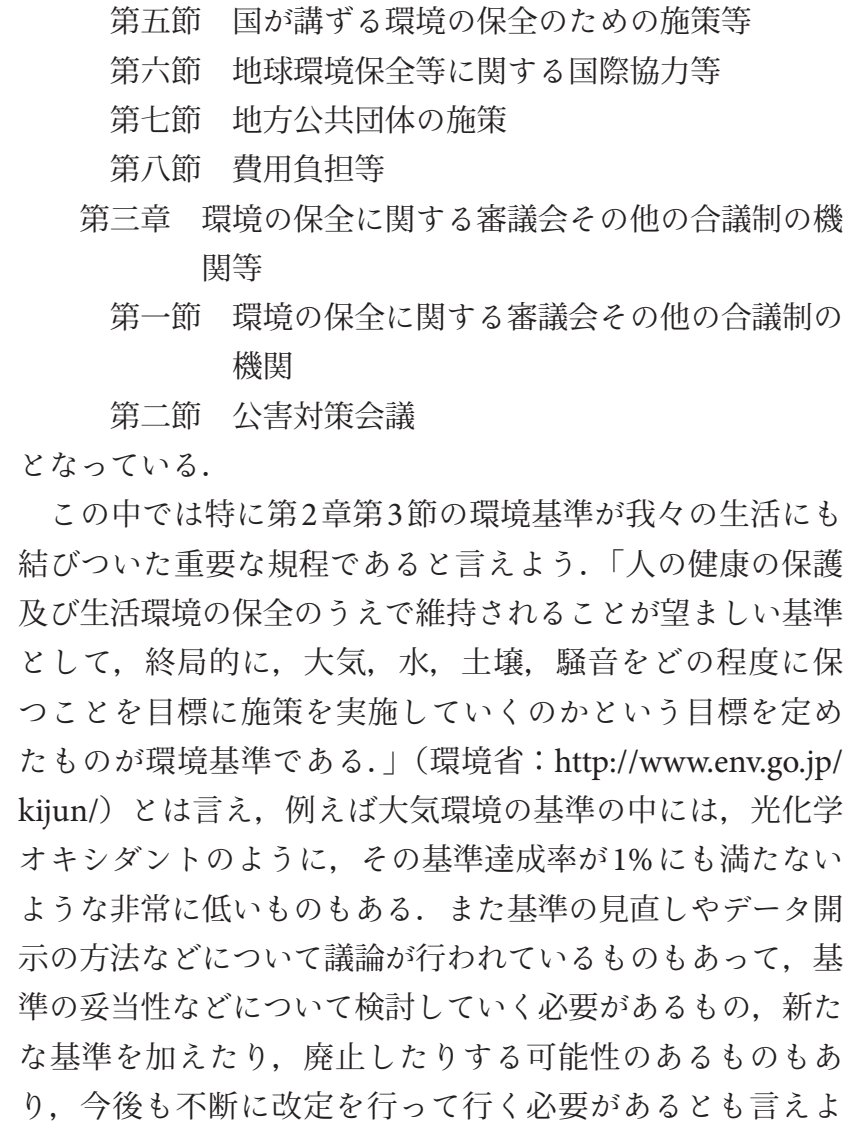

第五節＼cjkstart国が講ずる環境の保全のための施策等

第六節 地球環境保全等に関する国際協力等

第七節 地方公共団体の施策

第八節 費用負担等

第三章＼cjkstart環境の保全に関する審議会その他の合議制の機 関等

第一節＼cjkstart環境の保全に関する審議会その他の合議制の 機関

第二節 公害対策会議

となっている.

この中では特に第 2 章第 3 節の環境基準が我々の生活にも 結びついた重要な規程であると言えよう。「人の健康の保護 及び生活環境の保全のうえで維持されることが望ましい基準 として, 終局的に, 大気, 水, 土壤, 騒音をどの程度に保 つことを目標に施策を実施していくのかという目標を定め たものが環境基準である.」（環境省：http://www.env.go.jp/ $\mathrm{kijun} /$ ）とは言え, 例えば大気環境の基準の中には, 光化学 オキシダントのように，その基準達成率が $1 \%$ に満たない ような非常に低いものもある. また基準の見直しやデータ開 示の方法などについて議論が行われているものもあって, 基 準の妥当性などについて検討していく必要があるもの, 新た な基準を加えたり，廃止したりする可能性のあるものもあ り, 今後も不断に改定を行って行く必要があるとも言えよ 
う.

\section{1. この法律の目的と理念}

本法律の目的や理念は第 1 章の総則に記述されている. 産業革命以降，人間の活動によって自然界にインプットさ れる様々なもの（物質のみでなく, 騒音や光のような物理現 象も含む）が増加し，それか潘って人間の健康や生活，さら には動植物などの生態系に与える影響が看過できないレベル となってきた。これらの人間活動に由来する，人間の健康に 影響を及ぼすものとして，いわゆる7つの典型公害というも のが規定され，それらに対する対策を定めるものとして昭和 42 年に公害対策基本法が制定された。この法律に規定され た典型7公害とは大気の污染, 水質の污濁, 土㙵の污染, 騒 音, 振動, 地盤の沈下及び悪臭であり, この法律によって人 の健康又は生活環境に係る被害が生ずることを防ごうという 目的の法律であった. しかし, 環境問題が複雑化し, また成 層圈のオゾン層破壊や地球温暖化問題など,「公害」の枠組 みでは規定できない地球規模の環境問題が涌き起こり, これ らを含めたより広範囲な環境問題に対処するため, 平成 5 年 に環境基本法か制定された。

本法律の目的は第 1 条に「この法律は, 環境の保全につい て，基本理念を定め，並びに国，地方公共団体，事業者及び 国民の責務を明らかにするとともに，環境の保全に関する施 策の基本となる事項を定めることにより，環境の保全に関す る施策を総合的かつ計画的に推進し，もって現在及び将来の 国民の健康で文化的な生活の確保に寄与するとともに人類 の福祉に貢献することを目的とする.」と定められたように, 環境の保全に関する施策の基本事項を定めて，国民の健康で 文化的な生活の確保に寄与すること，と規定されている.

また第2条には，この法律で言う「環境負荷」の定義とし て, 地球規模環境問題につながる事象と，公害対策基本法に 示された7つの公害があげられている.

また，環境保全の基本理念として，第 3 条〜第 5 条に

（1）現在及び将来の世代の人間か環境の恵みを享受し, 将来 に継承すること

（2）全ての者の公平な役割分担の下，環境への負担の少ない 持続的発展が可能な社会が構築されること

（3）国際的協調により積極的に地球環境保全を推進すること が挙げられている.

そのため，国，地方公共団体，事業者，国民がそれぞれ務 めるべき責務が規定されている，我々国民は，第 9 条に規定 されているように「国民は, 基本理念にのっとり, 環境の保 全上の支障を防止するため, その日常生活に伴う環境への負 荷の低減に努めなければならない，2 前項に定めるものの ほか，国民は，基本理念にのっとり，環境の保全に自ら努め るとともに，国又は地方公共団体が実施する環境の保全に関 する施策に協力する責務を有する.」のである.

\section{2. 環境の保全に関する基本的施策}

第 2 章は本法律の根幹となるべき部分で, 第 1 節に施策の 策定等に係る指針，第2節に環境基本計画，第3節に環境基 準，第4節に特定地域における公害の防止，第5節に国が講 ずる環境の保全のための施策等, 第6節に地球環境保全等に 関する国際協力等，第7節に地方公共団体の施策，第 8 節に 費用負担等，と単に理念上のことだけでなく，具体的な環 境対策につながる事項が規定されている，特に環境基準は， 我々が様々な環境問題に向き合うときに, 常に参照すべき基 準が列挙されており, 重要な基準データであると言うことが できる。

第 1 節の施策の策定等に係る指針では，第 14 条に環境の 保全に関する施策の策定及び実施に当たって旨とすべきこと が3点示されている。それらは

（1）大気, 水, 土袞その他の環境の自然的構成要素が良好な 状態に保持されること

（2）生物の多様性の確保が図られ, 多様な自然環境が地域の 自然的社会的条件に応じて体系的に保全されること

（3）人と自然との豊かな触れ合いが保たれること である.

このような指針に基づき，第2節第15条において「政府 は，環境の保全に関する施策の総合的かつ計画的な推進を図 るため, 環境の保全に関する基本的な計画（以下「環境基本 計画」という.）を定めなければならない.」として，環境基 本計画の策定を定めている，そして，以下の各条において国 の具体的な施策を示している.

-大気污染，水質污濁，土壌污染，騒音に係る環境基準（第 16条)

・公害防止計画及びその達成の推進（第 17,18 条）

・環境配慮 一国の施策の策定（第19条） 一環境影響評価の推進（第20条）

- 規制（第21条）

- 経済的措置 一経済的助成, 経済的負担による誘導（第 22条)

・環境への負荷低減に資する製品等の利用（第23条）

・環境の保全に関する教育・学習（第25条）

・民間団体等の自発的な活動の促進（第26条）

・施策の策定に必要な調査の実施，監視等の体制の整備（第 28,29条)

・科学技術の振興（第 30 条）

・公害による紛争の処理（第31条）

・地球環境保全等に関する国際協力（第32～35条）

\section{3. 環境基準}

本稿の読者にとって最も関心があるのはやはり環境基準で はないかと思われるので，環境基準について少し詳しく触れ 
ることにしょう。ここでは，すべての条項について列挙する スペースはないので，主に筆者の専門とする大気污染に関す る環境基準を中心に見ていくことにしたい.

なお，環境基本法第 16 条では「政府は，大気の污染，水 質の污濁，土壌の污染及び騒音に係る環境上の条件につい て，それぞれ，人の健康を保護し，及び生活環境を保全する 上で維持されることが望ましい基準を定めるものとする.」 としている，この環境基準は環境省の HP (http://www.env. go.jp/kijun/）の解説に「環境基準は，『維持されることが望 ましい基準』であり，行政上の政策目標である。これは，人 の健康等を維持するための最低限度としてではなく，より積 極的に維持されることが望ましい目標として，その確保を 図っていこうとするものである.」とあるように，最低基準 ではなく維持されることが望ましい目標である。したがっ て，この基準值を少し超えたからといって，すぐに健康に とって害があるというレべルのものではない，マスコミ等で よく，環境基準值を少し超えるとすぐに「注意すべき」との 報道がなされるが，報道のあり方を一考すべきではないかと 考えられる。また，PM2.5などにおいては，その発生源につ いても，一般的には中国が発生源と見なされがちだが，最近 の環境省の発表（http://www.env.go.jp/press/100798.html） によれば，特に夏場においては国内における光化学スモッグ の影響も無視できないものとなっているようである．偏った
見方をしないように注意すべきであろう.

\section{1. 大気の環境基準}

大気に関する環境基準としてはまず二酸化硫黄 $\left(\mathrm{SO}_{2}\right)$, 一酸化炭素 $(\mathrm{CO})$, 二酸化窒素 $\left(\mathrm{NO}_{2}\right)$, 光化学オキシダン トが挙げられる。これに加えて大気中の粒子状物質である浮 遊粒子状物質（SPM）と微小粒子状物質（PM2.5）に対する 環境基準が定められている。これらを以下の表 1 に示した。

環境基準の設定に際しては，これに対応する公定の測定 法が付記されている. 当初は主に溶液を用いたいわゆる wet chemistryによる測定が中心であり, 光化学オキシダントや $\mathrm{SO}_{2}, \mathrm{NO}_{2}$ などの主要なガス状大気污染物質もそれぞれ溶液 を用いた分析が行われていた．大気污染のモニタリングが地 方自治体を中心に幅広く行われるようになると，これら溶液 を用いた分析も自動化され，非常に精巧な測定機が構築され ていった。しかし, 溶液を用いた分析では, 試薬の補充や, 廃液の回収が必要であるため, 長期間の測定には人手がかか るという問題点があった。 その後, 気相における蛍光や化学 発光など光学的な手法を取り入れた，いわゆる乾式の測定法 が進歩し, 安定的な測定が可能になるにつれて, これらによ るモニタリングが普及し, 公定の大気污染測定法にも乾式機 器による分析が追加されるようになり，現在ではほとんどの ガス状大気污染物質が乾式測定法で測定されるようになって

表 1. 環境基準と公定測定法

\begin{tabular}{|c|c|c|}
\hline 物質 & 環境上の条件（設定年月日等） & 測定方法 \\
\hline 二酸化いおう（ $\left.\mathrm{SO}_{2}\right)$ & $\begin{array}{l}1 \text { 時間值の } 1 \text { 日平均值が } 0.04 \mathrm{ppm} \text { 以下であり，かつ, } \\
1 \text { 時間值が } 0.1 \mathrm{ppm} \text { 以下であること.（48.5.16告示） }\end{array}$ & 溶液導電率法又は紫外線蛍光法 \\
\hline 一酸化炭素（CO） & $\begin{array}{l}1 \text { 時間值の } 1 \text { 日平均值が } 10 \mathrm{ppm} \text { 以下であり, かつ, } \\
1 \text { 時間值の } 8 \text { 時間平均值が } 20 \mathrm{ppm} \text { 以下であること. } \\
(48.5 .8 \text { 告示 })\end{array}$ & 非分散型赤外分析計を用いる方法 \\
\hline 浮遊粒子状物質（SPM） & $\begin{array}{l}1 \text { 時間值の } 1 \text { 日平均值が } 0.10 \mathrm{mg} / \mathrm{m}^{3} \text { 以下であり, か } \\
\text { つ, } 1 \text { 時間值が } 0.20 \mathrm{mg} / \mathrm{m}^{3} \text { 以下であること.（48.5.8 } \\
\text { 告示） }\end{array}$ & $\begin{array}{l}\text { 濾過捕集による重量濃度測定方法又はこの方法に } \\
\text { よって測定された重量濃度と直線的な関係を有する } \\
\text { 量が得られる光散乱法, 圧電天びん法若しくはべー } \\
\text { タ線吸収法 }\end{array}$ \\
\hline 二酸化窒素（ $\mathrm{NO}_{2} ）$ & 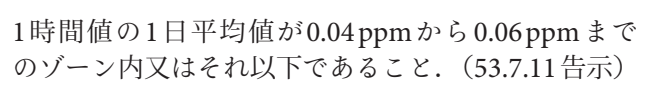 & $\begin{array}{l}\text { ザルツマン試薬を用いる吸光光度法又はオゾンを用 } \\
\text { いる化学発光法 }\end{array}$ \\
\hline 光化学オキシダント（OX） & 1時間值が $0.06 \mathrm{ppm}$ 以下であること.（48.5.8告示） & $\begin{array}{l}\text { 中性ヨウ化カリウム溶液を用いる吸光光度法若しく } \\
\text { は電量法, 紫外線吸収法又はエチレンを用いる化学 } \\
\text { 発光法 }\end{array}$ \\
\hline 微小粒子状物質 & $\begin{array}{l}1 \text { 年平均值が } 15 \mu \mathrm{g} / \mathrm{m}^{3} \text { 以下であり, かつ, } 1 \text { 日平均值 } \\
\text { が } 35 \mu \mathrm{g} / \mathrm{m}^{3} \text { 以下であること.（H21.9.9告示） }\end{array}$ & $\begin{array}{l}\text { 微小粒子状物質による大気の污染の状況を的確に把 } \\
\text { 握することができると認められる場所において, 濾 } \\
\text { 過捕集による質量濃度測定方法又はこの方法によっ } \\
\text { て測定された質量濃度と等価な值が得られると認め } \\
\text { られる自動測定機による方法 }\end{array}$ \\
\hline
\end{tabular}

備考

・環境基準は，工業専用地域，車道その他一般公衆が通常生活していない地域または場所については，適用しない。

・浮遊粒子状物質とは大気中に浮遊する粒子状物質であってその粒径が $10 \mu \mathrm{m}$ 以下のものをいう.

・微小粒子状物質とは，大気中に浮遊する粒子状物質であって，粒径が $2.5 \mu \mathrm{m}$ の粒子を $50 \%$ の割合で分離できる分粒装置を用いて，より粒径 の大きい粒子を除去した後に採取される粒子をいう。 


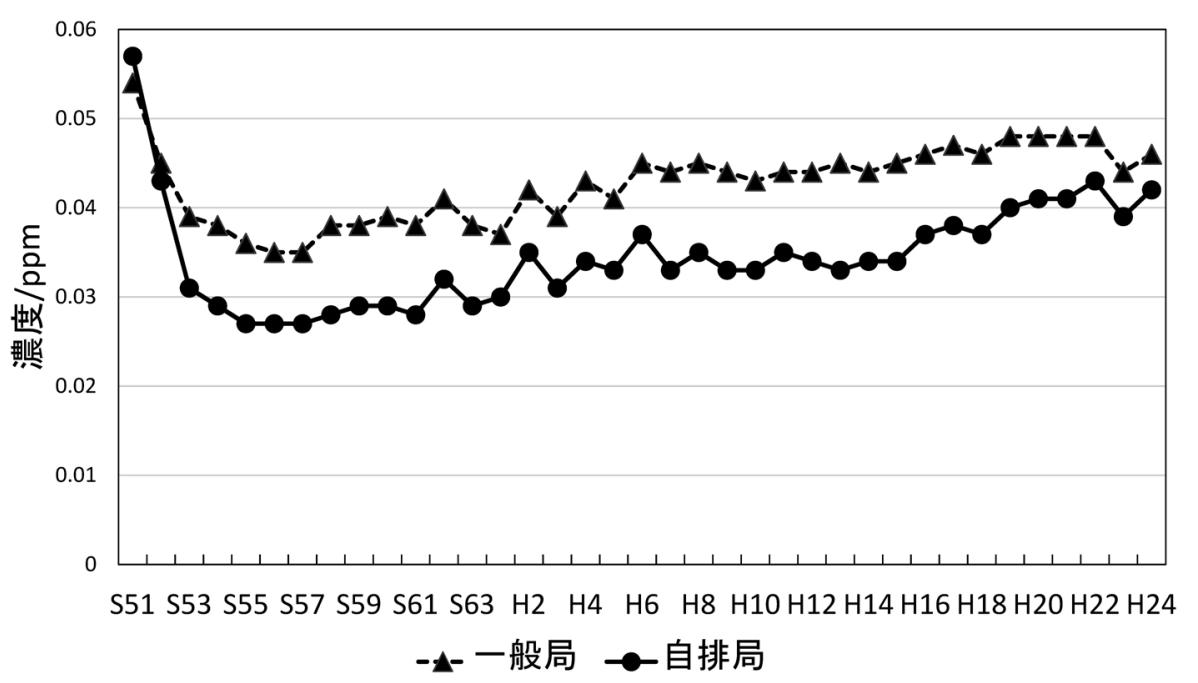

図 1. 光化学オキシダント（昼間の日最高 1 時間値）の年平均值の推移（環境省 $\mathrm{H} 24$ 大気污染状況報告書より）。図中の一般局とは一般環境 大気測定局の略称で，一般環境大気の污染状況を常時監視する測定局であり，2012年度には616市町村に1,178局が設置されていた。また自 排局とは自動車排出ガス測定局の略称で, 自動車走行による排出物質に起因する大気污染の考えられる交差点, 道路及び道路端付近の大気 を対象にした污染状況を常時監視する測定局のことであり，2012年度には25市町村に30局が設置されていた。

いる．例えば，オキシダントに対する乾式の公定測定法はい ずれも通常のいわゆるオゾン計であるので, 現在光化学オキ シダントとして報告されている值はオゾンの濃度であると 言っても過言ではない.

3.1.1. 光化学オキシダントの増加傾向

我が国においては $\mathrm{SO}_{2} や \mathrm{NO}_{2}$ については, かつての大気 污染状況から脱して, 環境基準はほぼ達成されている。これ に対して光化学オキシダントについては環境基準の達成率 (1 時間值の年間最高值が $0.06 \mathrm{ppm}$ を超えない測定局数の割 合. 年間に 1 日でも $0.06 \mathrm{ppm}$ を超えると, 残りの 364 日間の 濃度がこれ以下であっても環境基準非達成ということになる ので，非常に厳しい值であるとは言える）は依然 $1 \%$ 以下で ある. 図 1 に示すように, 全国平均のオキシダント濃度は依 然増加傾向にある。

対流圈大気中のオゾンは $\mathrm{NO}_{2}$ と, 炭化水素などの VOC （揮発性有機化合物）に太陽光が作用することによって発 生することが知られている. 日本国内に扔ける $\mathrm{NO}_{2}$ 抢よび VOCの濃度はいずれも減少傾向にあるにもかかわらず, 光 化学オキシダント（オゾン）の濃度が上昇している原因はな かなか難しく, 今も研究が進められているところである.

\subsubsection{PM2.5 の環境基準}

平成 25 年の 1 月に中国の北京周辺で PM2.5が高濃度に発 生して，日本でも大きな社会問題になったことは記憶に新し い. 大気中に浮遊している微小な粒子状の物質はエアロゾ ルと呼ばれる。このような粒子状物質のうち, 大気中での 化学反応などによりガス状物質から粒子状物質への転換に より生成する二次粒子はその粒子の直径が $2.5 \mu \mathrm{m}$ 以下の微 小粒径域に存在し PM2.5と呼ばれている（図2). 粒径の大 きな粒子が呼吸において鼻やのどの粘膜で捕捉されるのに対

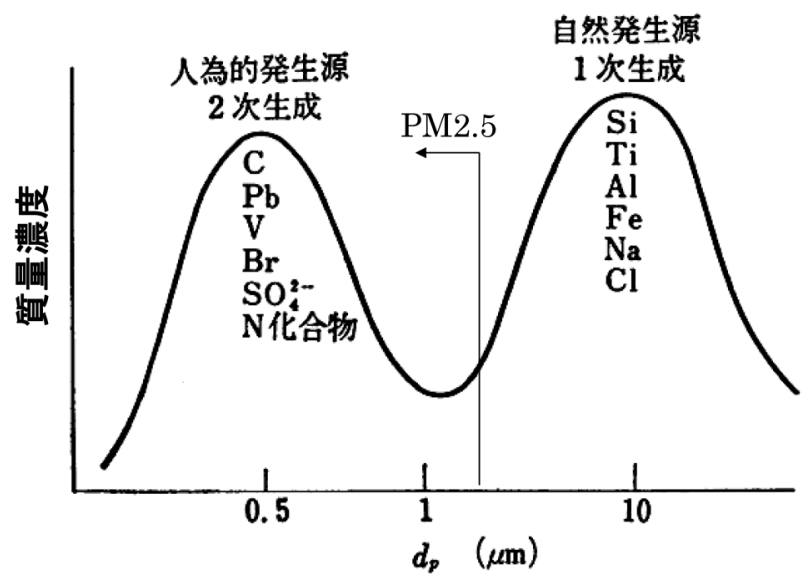

図2. エアロゾル質量濃度の粒径分布と PM2.5（文献1）より改 変).

表 2. 日本，米国，中国の PM2.5 環境基準及びWHO の指針

\begin{tabular}{lll}
\hline & 年平均值 $\left(\mu \mathrm{g} / \mathrm{m}^{3}\right)$ & 日平均值 $\left(\mu \mathrm{g} / \mathrm{m}^{3}\right)$ \\
\hline 日本 & 15 & 35 \\
米国 & $12^{\mathrm{a})}$ & 35 \\
中国 & $35^{\mathrm{b})}$ & $75^{\mathrm{b})}$ \\
WHO指針 & 10 & 25 \\
\hline
\end{tabular}

a) 2013 年 3 月, 米国は基準值を $15 \mu \mathrm{g} / \mathrm{m}^{3} \rightarrow 12 \mu \mathrm{g} / \mathrm{m}^{3}$ へ強化した. b) 2012 年末から 74 都市で実施，2016年1月から全国施行.

して,このような微細な粒子は肺の中まで入ってしまうため 人間の健康に大きく関わっている. 表 1 には以前から環境基 準のあったSPM とともに, 平成 21 年に制定されたPM2.5の 環境基準も示してある. 日本, 米国, 中国の PM2.5 の環境 
基準を表2で比較した，米国では既に1997年（平成9年）に PM2.5 の環境基準が制定され，2013年には基準值を $15 \mu \mathrm{g} /$ $\mathrm{m}^{3}$ から $12 \mu \mathrm{g} / \mathrm{m}^{3}$ へと強化している。一方中国では $35 \mu \mathrm{g} / \mathrm{m}^{3}$ の環境基準が20112年に主要 74都市に設定され，2016年 1 月から全国に適用される.

アジアでは一次物質による環境污染が依然深刻であるが, 二次粒子やオゾンなどの二次生成物の越境大気污染も重要な 問題となりつつあり，広域な影響評価，地球温暖化対応策と 連動した削減方策の提言と実行は喫緊の課題である.

\section{2. 有害大気污染物質（ベンゼン等）に係る環境基準}

有害大気污染物質に関する環境基準は，大気污染防止法第 2条第 13 項の規定により，「継続的に摂取される場合には人 の健康を損なうおそれがある物質で大気の污染の原因となる もの」とされており，低濃度長期間暴露における有害性（長 期毒性）に着目して定められたものである。その施策は，同 法第 18 条の 20 の規定により,「科学的知見の充実の下に, 将 来にわたって人の健康に係る被害が未然に防止されるように することを旨として実施されなければならない」とされてい る。なかでも「有害大気污染物質のうち人の健康に係る被害 を防止するためその排出又は飛散を早急に抑制しなければ ならないもの」として大気污染防止法付則第 9 項で，指定さ れたベンゼン，トリクロロエチレン，テトラクロロエチレン の3物質と，平成 13 年 4 月 20 日，「ベンゼン，トリクロロエ チレン及びテトラクロロエチレンによる大気の污染に係る環 境基準についての一部改正について」(http://www.env.go.jp/ hourei/01/000025.html）で加えられたジクロロメタンにつ いて環境基準が設定されている（表3）.

\section{3. ダイオキシン類に係る環境基準}

ダイオキシンとは本来は図 3 のように酸素 2 個を含む 6 員 環の複素環式化合物のうち，二重結合が2個ある形のもの を意味する。図 3 は 6 員環の 1 と 4 の位置に酸素があるので, 1,4-ジオキシン（日本の化合物命名法では正式にはジオキシ ンと発音することになっている）と呼ばれる.

1,4-ジオキシン自体はそれほど安定な化合物ではないが, 2つの二重結合にベンゼン環が縮合すると非常に安定にな
る.これがジベンゾ 1,4-ジオキシン（図 4) である.このジ ベンゾ1,4-ジオキシンのベンゼン環に塩素が置換されると （ポリ塩化ジベンゾ1,4-ジオキシン）非常に毒性が高いこと が知られており，これに環境基準が制定されている，中でも 2つの酸素原子から遠い位置の 4 箇所（2,3,7,8 の位置）に4 つの塩素が入った $2,3,7,8$-テトラクロロジベンゾ-1,4-ジオキ シン（TCDD）は最も毒性が高い。また，これらジオキシン

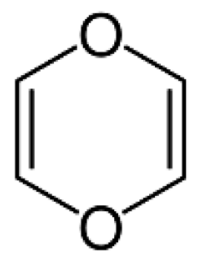

図3.1,4-ジオキシン

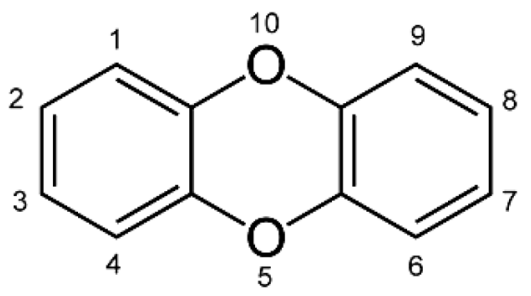

図4. ジベンゾ1,4-ジオキシン

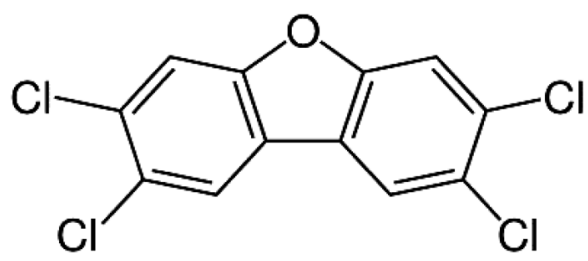

図5. ポリ塩化ジベンゾフラン

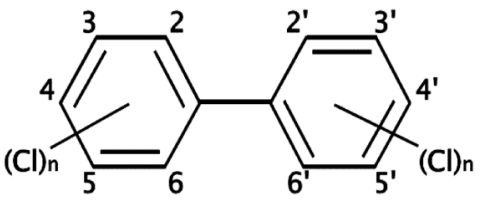

図6. ポリ塩化ビフェニル：2つのベンゼン環が同一平面にある ものが毒性が高くダイオキシン類に入る（コプラナー PCB）.

表3. 有害大気污染物質（ベンゼン等）に係る環境基準

\begin{tabular}{lll}
\hline \multicolumn{1}{c}{ 物質 } & \multicolumn{1}{c}{ 環境上の条件 } & 測定方法 \\
\hline ベンゼン & 1 年平均值が $0.003 \mathrm{mg} / \mathrm{m}^{3}$ 以下であること. (H9.2.4告示) & キャニスター又は捕集管により採取した試料をガス \\
トリクロロエチレン & 1 年平均值が $0.2 \mathrm{mg} / \mathrm{m}^{3}$ 以下であること. (H9.2.4告示) & クロマトグラフ質量分析計により測定する方法を標 \\
テトラクロロエチレン & 1 年平均值が $0.2 \mathrm{mg} / \mathrm{m}^{3}$ 以下であること. (H9.2.4告示) & 準法とする. また, 当該物質に関し, 標準法と同等 \\
ジクロロメタン & 1 年平均值が $0.15 \mathrm{mg} / \mathrm{m}^{3}$ 以下であること. (H13.4.20告示) & 以上の性能を有使用可能とする.
\end{tabular}

備考

・ベンゼン等による大気の污染に係る環境基準は, 継続的に摂取される場合には人の健康を損なうおそれがある物質に係るものであることにか んがみ, 将来にわたって人の健康に係る被害が未然に防止されるようにすることを旨として，その維持又は早期達成に努めるものとする. 
表4. ダイオキシン類に関する環境基準

\begin{tabular}{|c|c|c|}
\hline 媒体 & 環境上の条件 & 測定方法 \\
\hline 大気 & $\begin{array}{l}1 \text { 年平均值が } 0.6 \mathrm{pg}-\mathrm{TEQ} / \mathrm{m}^{3} \text { 以下である } \\
\text { こと. (H11.12.27告示) }\end{array}$ & $\begin{array}{l}\text { ポリウレタンフォームを装着した採取筒をろ紙後段に取り付けた } \\
\text { エアサンプラーにより採取した試料を高分解能ガスクロマトグラ } \\
\text { フ質量分析計により測定する方法. }\end{array}$ \\
\hline 水質（水底の底質を除く） & $1 \mathrm{pg}-\mathrm{TEQ} / 1$ 以下 & 日本工業規格 K0312 に定める方法 \\
\hline 水底の底質 & $150 p g-T E Q / g$ 以下 & $\begin{array}{l}\text { 水底の底質中に含まれるダイオキシン類をソックスレー抽出し, } \\
\text { 高分解能ガスクロマトグラフ質量分析計により測定する方法 }\end{array}$ \\
\hline 土堙 & 1,000 pg-TEQ/g以下 & $\begin{array}{l}\text { 土㙴中に含まれるダイオキシン類をソックスレー抽出し, 高分解 } \\
\text { 能ガスクロマトグラフ質量分析計により測定する方法（ポリ塩化 } \\
\text { ジベンゾフラン等（ポリ塩化ジベンゾフラン及びポリ塩化ジベン } \\
\text { ゾ-パラ-ジオキシンをいう. 以下同じ.）及びコプラナーポリ塩化 } \\
\text { ビフェニルをそれぞれ測定するものであって, かつ, 当該ポリ塩 } \\
\text { 化ジベンゾフラン等を2種類以上のキャピラリーカラムを併用して } \\
\text { 測定するものに限る.) }\end{array}$ \\
\hline
\end{tabular}

備考

・基準值は, 2,3,7,8-四塩化ジベンゾ-パラ-ジオキシンの毒性に換算した值とする.

・大気及び水質（水底の底質を除く）の基準值は，年間平均值とする.

と類似の構造を取って, やはり毒性があるポリ塩化ジベンゾ フラン（図5）とポリ塩化ビフェニル（いわゆる $\mathrm{PCB}$; 図6） についてもポリ塩化ジベンゾジオキシンと一緒に環境基準の 対象とされており，これらを合わせてダイオキシン類と総称 されている．ダイオキシン類の環境中濃度の基準は，現在は ダイオキシン類対策特別措置法に基づき設定されていて, 環 境基本法そのものではないが, 密接に関連するので, ここで 触れておくことにしたい.この法律ではダイオキシン類によ る大気の污染, 水質の污濁（水底の底質の污染を含む）及び 土壌の污染に係る環境基準が定められている（表4）。この 法律では第 1 条において「この法律は, ダイオキシン類が人 の生命及び健康に重大な影響を与えるおそれがある物質であ ることにかんがみ, ダイオキシン類による環境の污染の防止 及びその除去等をするため, ダイオキシン類に関する施策の 基本とすべき基準を定めるとともに，必要な規制，污染土壌 に係る措置等を定めることにより，国民の健康の保護を図る ことを目的とする.」とその目的を定めている.

ダイオキシン類には多くの異性体や同族体が含まれる。そ れぞれの化合物の毒性はそれぞれ異なるため，ダイオキシン 類全体の毒性を検討するため, 最も毒性が高いとされている 2,3,7,8-テトラクロロジベンゾ-1,4-ジオキシンを基準に，各 分子に対して 2,3,7,8-テトラクロロジベンゾ-1,4-ジオキシン の毒性に換算した值（毒性当量因子TEF; Toxicity Equivalency Factor; 表 5）を用いて計算し，それらの合計をダイオ キシン類の毒性としている.このように換算した值のことを TEQ（Toxicity Equivalency Quantity）と呼んでいる. 大気, 水質，土壌に対する環境基準はいずれもこの TEQを用いて 示されている.

これらの基準はいずれも耐容一日摂取量（TDI）, つまり, 人が生涯にわたり摂取しても健康に対する有害な影響が現れ
表 5. 毒性当量因子（国際毒性等価係数）

\begin{tabular}{lll}
\hline \multicolumn{1}{c}{ 種類 } & \multicolumn{1}{c}{ 化学物質 } & TEF \\
\hline PCDD (ポリ塩化ジベンゾジ & $2,3,7,8-\mathrm{TCDD}$ & 1 \\
オキシン) & $1,2,3,7,8-\mathrm{PeCD}$ & 0.5 \\
& $1,2,3,4,7,8-\mathrm{HxCDD}$ & 0.1 \\
& $1,2,3,6,7,8-\mathrm{HxCDD}$ & 0.1 \\
& $1,2,3,7,8,9-\mathrm{HxCDD}$ & 0.1 \\
& $1,2,3,4,6,7,8-\mathrm{HpCDD}$ & 0.01 \\
& $\mathrm{OCDD}$ & 0.0001 \\
ラCDF（ポリ塩化ジベンゾフ & $2,3,7,8-\mathrm{TCDF}$ & 0.1 \\
& $1,2,3,7,8-\mathrm{PeCDF}$ & 0.05 \\
& $2,3,4,7,8-\mathrm{PeCDF}$ & 0.5 \\
& $1,2,3,4,7,8-\mathrm{HxCDF}$ & 0.1 \\
& $1,2,3,6,7,8-\mathrm{HxCDF}$ & 0.1 \\
& $1,2,3,7,8,9-\mathrm{HxCDF}$ & 0.1 \\
& $2,3,4,6,7,8-\mathrm{HxCDF}$ & 0.1 \\
& $1,2,3,4,6,7,8-\mathrm{HpCDF}$ & 0.01 \\
& $1,2,3,4,7,8,9-\mathrm{HpCDF}$ & 0.01 \\
& $\mathrm{OCDF}$ & 0.001 \\
& $3,3^{\prime}, 4,4^{\prime}-\mathrm{TCB}(77)$ & 0.0001 \\
& $3,4,4^{\prime}, 5-\mathrm{TCB}(81)$ & 0.0001 \\
& $3,3^{\prime}, 4,4^{\prime}, 5-\mathrm{PeCB}(126)$ & 0.1 \\
& $3,3^{\prime}, 4,4^{\prime}, 5,5^{\prime}-\mathrm{HxCB}(169)$ & 0.01 \\
\hline
\end{tabular}

$\mathrm{Pe}=$ ペンタ, $\mathrm{Hx}=$ ヘキサ, $\mathrm{Hp}=$ ヘプタ, $\mathrm{O}=$ オクタ.

ないと判断される一日体重 $1 \mathrm{~kg}$ 当たりの摂取量 ( $4 \mathrm{pg}$-TEQ ／体重 $\mathrm{kg} /$ 日）を超えないことを目安に設定されたものと 言えよう. 


\section{4. その他の環境基準}

上記した大気に関する環境基準の他に，騷音，水質，土袞 に対する環境基準が定められている.

3.4.1. 水質に関する環境基準

水質に関しては，(1）人の健康の保護に関する環境基準 と，(2）生活環境の保全に関する環境基準，があり，また地 下水に対する環境基準も別途定められている.

（1）は人の健康の保護に関する環境基準で, 全公共用水 域につき, カドミウム, 全シアン, 鉛, 六価クロム, 砒素, 総水銀, アルキル水銀, $\mathrm{PCB}$, ジクロロメタン, 四塩化炭 素，1,2-ジクロロエタン，1,1-ジクロロエチレン，シス-1,2ジクロロエチレン，1,1,1-トリクロロエタン，1,1,2-トリク ロロエタン, トリクロロエチレン, テトラクロロエチレン, 1,3-ジクロロプロペン, チウラム, シマジン, チオベンカル ブ，ベンゼン，セレン，硝酸性窒素及び亜硝酸性窒素，ふっ 素，ほう素，1,4-ジオキサンの 27 項目について基準が示され ている。（2）は生活環境の保全に関する環境基準で，河川 と湖沼については水素イオン濃度 $(\mathrm{pH})$, 化学的酸素要求量 (COD), 浮遊物質量 $(\mathrm{SS})$, 溶存酸素量 $(\mathrm{DO})$, 大腸菌群 数についての, 海域に関しては水素イオン濃度 $(\mathrm{pH})$, 化学 的酸素要求量 $(\mathrm{COD})$, 溶存酸素量 (DO), 大腸菌群数, $n-$ ヘキサン抽出物質（油分等）についての基準が設定されてい る. 地下水に関する環境基準については（1）に挙げられて いる 27 種の物質に加えて塩化ビニルモノマーに関する基準 がある.

いずれも，詳細については環境省の HP（http://www.env. go.jp/kijun/mizu.html）を参照されたい。ここには各污染物 質の測定法に関する詳細が13の付表として添付されており， 参考となるものである.

3.4.2. 土㙵に関する環境基準

土壌に関する環境基準はカドミウム，全シアン，有機燐 （りん）, 鉛，六価クロム，砒（ひ）素, 総水銀, アルキル 水銀, $\mathrm{PCB}$, 銅, ジクロロメタン, 四塩化炭素, 1,2-ジクロ ロエタン，1,1-ジクロロエチレン，シス-1,2-ジクロロエチレ ン，1,1,1-トリクロロエタン，1,1,2-トリクロロエタン， ト
リクロロエチレン，テトラクロロエチレン， 1,3-ジクロロプ ロペン, チウラム, シマジン, チオベンカルブ, ベンゼン, セレン，ふっ素，ほう素の27項目について示されている。 詳細についてはやはり環境省のHP（http://www.env.go.jp/ kijun/dojou.html）およびその別表（http://www.env.go.jp/ kijun/dt1.html）を参照して頂きたい. 各污染物質の測定法 については，同じく付表（http://www.env.go.jp/kijun/dt1-1. html）に詳しく規定されていて，参考になる。

\section{おわりに}

以上，環境基本法を概観し，その中心である環境基準につ いて主に大気に関する環境基準について解説した．本学会の 会員諸氏にとっては，水質や土壌に関する環境基準に興味の 中心があるのではないかと思われるが，筆者の浅学により， これらについては詳しく解説することはできなかった．深く お詫びする次第である．本稿の中で紹介した環境省の HPに はこれらに関する詳しいデータが揭載されているので，そち らをご覧頂けたら幸いである。

\section{引 用 文 献}

1）高橋幹二編著：応用エアロゾル学，養賢堂，p. 58, 1984.

\section{略 歴 \\ 畠山史郎（はたけやましろう） \\ 生年月日：1951年1月31日 \\ 最終学歴：1979年3月東京大学大学院理学系研究科博士課程 修了 (理学博士) \\ 研究テーマ: 大気中の化学反応の機構解明と長距離越境大気 污染中の微小粒子の輸送・変質プロセスの解明 \\ 主な職歴：1979年4月国立公害研究所（現・国立環境研究所） 大気環境部研究員. 同主任研究員, 地球環境研究 センター研究管理官, 大気反応研究室長, アジア 広域大気研究室長などを経て，2007年4月ょり東 京農工大学大学院農学研究院教授.}

趣味：スキー, 軽登山, 音楽鑑賞 